\title{
Analisis Perjanjian Modal Ventura Pola Bagi Hasil antara Kitab Undang-Undang Hukum Perdata dan Kompilasi Hukum Ekonomi Islam
}

\author{
F. Setiawan Santoso
}

Fakultas Agama Islam, Universitas Cokroaminoto Yogyakarta

Email: Fattah_ss@yahoo.com

\begin{abstract}
One resolution of moral hazard in venture capital (CV) is clarity and certainty in his Covenant. This article about it by analyzing the juridical basis of the Covenant pattern for CV results within the scope of KUHPerdata and KHES of mudarabah in solving CV. With this initial exploration is expected to be able to make a donation to the religious courts in Indonesias practitioners who still recognize both the economic problems of the Sharia in the settlement that became his authority. Both views do not differ greatly in resolving issues of venture capital can even complement each other's weaknesses in deciding the problems of venture capital.
\end{abstract}

Keywords: Venture capital, profit and loss sharing, civil code, Islamic law

\begin{abstract}
Abstrak
Salah satu penyelesaian moral hazard dalam modal ventura (MV) adalah kejelasan dan kepastian dalam perjnajiannya. Tulisan ini tentang hal itu dengan menganalisis secara yuridis tentang perjanjian MV dengan pola bagi hasil dalam lingkup KUHPerdata dan KHES tentang mudarabah dalam menyelesaiakan permasalahan MV. Dengan eksplorasi awal ini diharapkan bisa memberikan sumbangan bagi praktisi peradilan agama di Indonesias yang masih mengakui keduanya dalam penyelesaian permasalahan ekonomi syariah yang menjadi wewenangnya. Pandangan keduanya tidak berbeda jauh dalam meneyelesaikan persoalan modal ventura bahkan bisa saling melengkapi kelemahan dalam memutuskan permasalahan modal ventura.
\end{abstract}

Kata kunci: Modal Ventura, bagi hasil, perusahaan modal ventura, perusahaan pasangan usaha. 


\section{Pendahuluan}

Indonesia dewasa ini telah mengalami perkembangan pesat dalam pertumbuhan ekonominya. Sektor riil tidak lagi bertumpu kepada industri nasional dan multi nasional. Usaha kecil dan menengah (UMKM) telah berdiri sejajar dengan usaha berskala besar karena andil usaha mereka dalam perekonomian negara hampir sama tinggi dengan usaha lainnnya. Perkembangan itu telah mendesak kepada kebutuhan sumber pembiayaan alternative nonperbankan.

Pemerintah telah menetapkan strategi kebijakan diversivikasi lembaga pembiayaan non-perbankan yang salah satunya adalah modal ventura (MV). Lembaga itu adalah salah satu bentuk usaha di bidang lembaga keuangan bukan bank yang mempunyai peranan sangat penting dalam pembiayaan. Kegiatan lembaga pembiayaan ini dilakukan dalam bentuk penyediaan dana atau barang modal dengan tidak menarik dana secara langsung dari masyarakat dalam bentuk giro, deposito, tabungan, dan surat sanggup bayar. Fuady menegaskan modal ventura sebagai suatu pembiayaan oleh perusahaan modal ventura (investor) dalam bentuk penyertaan modal ke dalam suatu perusahaan yang menerima bantuan pembiayaan untuk jangka waktu tertentu, di mana setelah jangka waktu tersebut lewat, pihak investor akan melakukan divestasi atas saham-sahamnya itu.( Simorangkir, 2004: 170)

Dalam Peraturan Otoritas Jasa Keuangan Nomor 35/Pojk.05/2015 Tentang Penyelenggaraan Usaha Perusahaan Modal Ventura mendefinisikan Usaha Modal Ventura sebagai usaha pembiayaan melalui penyertaan modal dan/atau pembiayaan untuk jangka waktu tertentu dalam rangka pengembangan usaha pasangan usaha atau debitur. Perusahaannya disebut perusahaan modal ventura (PMV) dan perusahaan pasangan usaha disingkat PPU.

Cross dalam Simorangkir menjelaskan modal ventura merupakan pembiayaan yang mengandung resiko tinggi. bentuk umunya adalah partisipasi modal terhadap perusahaan-perusahaan berpotensi pertumbuhan tinggi. PMV kemudian menyediakan beberapa nilai tambah dalam bentuk masukan manajemen dan memberikan kontribusinya terhadap keseluruhan strategi perusahaan yang bersangkutan. Resiko yang relatif tinggi ini akan dikompensasikan dengan kemungkinan hasil yang tinggi pula. kompensasi 
Analisis Perjanjian Modal Ventura Pola Bagi Hasil antara Kitab Undang...

ini didapatkan melalui keuntungan dari hasil penjualan dan penanaman modal yang bersifat jangka menengah.(Fuady, 2005: 125)

Salah satu pola pembiayaan MV berpola bagi hasil itu masih menyisakan resiko yang harus dipertimbangkan. Hubungan kemitraan di dalamnya memiliki pola sejajar sehingga memerlukan kejelasan mengingat kondisi PPU secara umum adalah perusahaan yang tidak memiliki akses terhadap pada kredit perbankan. (Fuady, 2006: 111-112) Dalam modal ventura, adanya perbedaan bentuk badan usaha pada PPU dapat berpengaruh pada pola hubungan hukum dengan Perusahaan Modal Ventura. Akibat perbedaan itu, masing-masing dari PPU memiliki karakteristik yang bervariasi. PMV harus menyikapinya saat mengadakan perjanjian modal ventura. Kesenjangan terjadi ketika hubungan hukum antara keduanya karena perjanjian modal ventura tidak sesuai dengan dengan acuan Pasal 1618 dan 1619 ayat (2) KUHPerdata tentang persekutuan perdata. Kemitraan ini juga dikenal dengan nama matschaap, yaitu perjanjian antara dua orang atau lebih mengikatkan diri untuk memasukan uang, barang ataupun keahlian ke dalam perjanjian dengan maksud membagi keuntungan.

Pola matschaap dalam modal ventura telah menjadikan hubungan PMV dan PPU dalam satu organisasi. Organisasi pengelolaan ini berhasil atau tidak ditentukan berdasar dari proses transformasi informasi antara semua pihak yang terlibat di dalamnya. Arus Informasi simetrik kemudian menjadi sangat penting, dan informasi asimetrik berdampak negative karena salah satu pihak menguasai informasi yang lebih banyak. Situasi asimetrik tersebut cenderung mendorong terjadinya apa yang disebut sebagai moral hazard terutama oleh pihak yang mempunyai sifat opportunis, yakni cenderung memanfaatkan kesempatan untuk keuntungan pribadi.

Hal ini akan menyebabkan ketidakefisienan suatu organisasi mengingat perilaku oportunistik cenderung mendorong orang untuk melakukan tindakan curang. Proses transformasi informasi akan melibatkan pihak-pihak yang berkepentingan. Dalam hal PMV, proses transformasi akan melibatkan PMV dan PPU. Hubungan kedua pihak ini sangat berbeda dengan karakteristik hubungan antara pihak bank dan pihak perusahaan sehingga naik turunnya tingkat bunga tidak bisa digunakan sebagai acuan untuk instrumen transaksi. Oleh karena itu, guna menjaga kesinambungan kerja sama usaha 
antara kedua pihak sangatlah ditentukan oleh perilaku (behaviour) pihakpihak yang terlibat baik secara personal antar pemegang saham, antara pemegang saham dan PMV, antara pemegang saham dan pengelola calon PPU, ataupun antar perusahaan tersebut.

Cara utama untuk menghindari moral hazard adalah mengikatkan kedua pihak dalam modal ventura dalam perjanjian yang mengikat dengan pola bagi hasil. Perjanjian antara PMV dan PPU perlu diteliti dipahami secara mendalam agar potensi permasalahan dalam hubungan kemitraaan tidak mengalami jalan buntu.

Bagi pengembangan hukum ekonomi Islam, pola kemitraan terutama dengan sistem bagi hasil dalam modal ventura memiliki kesesuaian dengan bentuk mudarabah.(Santoso, 2015: 39-49) Sistem bagi hasil adalah core dalam ekonomi Islam. Salah satu bentuknya adalah mudarabah. Dalam pasal 20 buku II Kompilasi Hukum Ekonomi Islam, Mudarabah merupakan kerjasama antara pemilik dana atau penanam modal dengan pengelola modal untuk melakukan usaha tertentu dengan pembagian keuntungan berdasarkan nisbah.

Analisis yuridis tentang perjanjian MV dengan pola bagi hasil ini dimaksudkan untuk mengetahui kekuatan dan kelemahan masing-masing material KUHPerdata dan KHES tentang mudarabah dalam menyelesaiakan permasalahan MV. Dengan eksplorasi awal ini diharapkan bisa memberikan sumbangan bagi praktisi peradilan agama di Indonesias yang masih mengakui keduanya dalam penyelesaian permasalahan ekonomi syariah yang menjadi wewenangnya.

\section{Perjanjian modal ventura pola bagi hasil}

Pelaksanaan perjanjian pembiayaan modal ventura dengan pola bagi hasil sangat bergantung terhadap perjanjian yang disepakati oleh dua belah pihak yang berkaitan. Meski demikian persyaratan pokoknya Untuk mencermati isi perjanjian, PMV sebagai pihak yang memberikan fasilitas pembiayaan dan PPU sebagai pihak yan menerima pembiayaan perlu memperhatikan syarat-syarat perjanjian yang ditentukan dalam Pasal 1320 KHUPerdata, yaitu : 
1. adanya kesepakatan dari para pihak;

2. kecakapan untuk membuat perjanjian;

3. obyek yang diperjanjikan; dan

4. sebab yang halal.

Sedangkan asas-asas hukum perjanjian dalam KUHPerdata yang perlu diperhatikan adalah Asas konsensualitas (Pasal 1320); Asas kebebasan berkontrak (Pasal 1338 ayat (1)) dan Asas Itikad baik (Pasal 1338 ayat (3))

Isi perjanjian yang ada biasanya meliputi beberapa hal selain identitas masing-masing pihak. Pasal 27 POJK Nomor 35/Pojk.05/2015 tentang Penyelenggaraan Usaha Perusahaan Modal Ventura menjabarkan perjanjiannya paling sedikit memuat: a. jenis kegiatan usaha; b. nomor dan tanggal perjanjian; c. identitas para pihak; d. jumlah penyertaan dan/atau pembiayaan; e. jangka waktu penyertaan dan/atau pembiayaan; f. tingkat pengembalian pembiayaan (jika ada); g. objek jaminan (jika ada); h. rincian biaya terkait dengan penyertaan/ pembiayaan yang diberikan yang paling sedikit memuat: 1 . biaya survey (jika ada); 2. biaya provisi (jika ada); 3. biaya notaris (jika ada); dan 4. biaya pengikatan jaminan (jika ada); i. ketentuan mengenai hak dan kewajiban para pihak; j. ketentuan mengenai denda (jika ada); dan k. mekanisme apabila terjadi perselisihan dan pemilihan tempat penyelesaian perselisihan.

Perjanjian modal ventura berjenis bagi hasil adalah sebagai berikut;

a. Jumlah pembiayaan

Jumlah pembiayaan harus disebutkan dengan jelas dengan satuan mata uang yang disepakati bersama.

b. Cara dan Jadwal penarikan atau pencairan modal

Jadwal penggunaan atau peneraikan modal harus dijelaskan dalam perjnajian sesuai dengan kebutuhan usaha PPU dan kesepakatan bersama.

c. Jangka waktu bantuan dana

Jangka waktu bantuan dana harus disebutkan dengan tegas, sehingga perusahaan pasangan usaha dapat membuat rencana kerja dari pembiayaan yang sesuai.

d. Bentuk balas jasa finansial

Bentuk balas jasa dari PPU dapat berupa bagi hasil dari keuntungan, biaya-biaya, dan lain-lain yang dijelaskan dalam perjanjian. 
e. Cara, jumlah, waktu pembayaran balas jasa finansial

Cara, jumlah, waktu pembayaran balas jasa finansial harus disebutkan dengan jelas. bagi hasil harus disertai juga proporsi masing-masing pihak berdasar periode usaha yang disepakati.

f. Cara penarikan kembali investasi (divestasi)

Divestasi dapat dilakukan dengan berbagai cara. Meski demikian jadawal perencanaan dan pelaksanaannya harus disepakati dulu di saat perjanjian

g. Syarat divestasi yang dipercepat

Keadaan tertentu adalah prasyarat pelaksanaan divestasi yang dipercepat tersebut. Beberapa keadaan itu antara lain : prospek PPU yang sangat diragukan, kerugian PPU yang sangat besar, krisis perekonomian, keuntungan atau perkembangan PPU yang terlalu besar, sehingga tidak lagi memerlukan bantuan modal ventura, atau keadaaan lainnya yang disepakati.

h. Perubahan atau pemindahan kepemilikan

Kesepakatan tentang adanya kemungkinan perubahan atau perpindahan kepemilikan atas PPU harus terungkap dalam akad.

Dalam pengaturan mudarabah dalam KHES muatan perjanjian juga mencakup aturan penyerahaan dana bagi usaha yang disepakati dalam akad perjanjian (Pasal 187). Aturan tentang bidang usaha,tempat, dan waktu yang bersifat bebas atau mengikat bisa diatur akad (pasal 189). Meski demikian mudarbah juga lebih jelas pengaturan tentang arti penting pemisahan modal dari harta kekayaan pribadi. Dalam pasal 200, Mudharib tidak boleh mencampurkan kekayaanya sendiri dengan harta kerjasama dalam melakukan mudharabah, kecuali bila sudah menjadi kebiasaan di kalangan pelaku usaha. Pasal 201 mengatur kebolehnannya jika mendapat izin dari pemilik modal dalam melakukan usaha-usaha khusus tertentu kemudian wajib dibagi secara proporsional atau atas dasar kesepakatan semua pihak.

\section{Hak dan kewajiban masing-masing pihak}

Hak dan kewajiban pihak yang memberikan modal ventura atau PMV dan pihak yang menerima modal ventura atau PPU, yaitu : (Rahman, 2003:118) 
a. Kewajiban

1) Kewajiban Perusahaan Modal Ventura

kewajiban utama perusahaan modal ventura hanya berupa penyediaan uang atau modal kepada PPU sesuai perjanjian kesepakatan. Kewajiban lain bersifat tambahan yang melindungi kepentingan PMV itu sendiri, antara lain :

a) pembinaan terhadap PPU, baik atas operasional, manajemen, dan keuangan yang usaha yang dibiayai olehnya.

b) Penyusunan pelaporan yang sesuai ketentuan pemerintah.

2) Kewajiban PPU

Kewajiban dari PPU, antara lain :

a) Mengembalikan modal yang telah diterimanya tersebut kepada perusahaan modal ventura setelah jangka waktu tertentu yang telah disepakati dalam perjanjian.

b) Membayar bagi hasil atas pemberian modal tersebut sebesar berapa yang telah disepakati dalam perjanjian.

b. Hak

1) Hak Perusahaan Modal ventura

Hak Perusahaan Modal Ventura, antara lain :

a) Berhak untuk mendapatkan pembayaran angsuran dan bagi hasil dari pembiayaan yang diberikan oleh PMV, sekaligus pinjaman pokoknya.

b) Berhak melakukan Divestasi, yaitu pelepasan investasi yang dilakukan PMV, apabila usaha dari PPU telah mencapai target.

c) Berhak menegur PPU yang wanprestasi.

2) Hak PPU

Hak PPU antara lain :

a) Berhak mendapatkan pelayanan dari PMV.

b) Berhak memperoleh modal dari PMV untuk menjalankan usahanya.

c) Berhak mendapatkan pembinaan dari PMV. 
Hak dan Kewajiban dalam perjanjian mengindikasikan modal ventura dengan pola bagi hasil merupakan suatu perjanjian dalam hal mana pihak yang satu (pihak pertama) berkewajiban menyerahkan sejumlah uang dan atau barang tertentu kepada dan untuk dipergunakan oleh pihak yang lain (pihak kedua) sebagai modal atau tambahan modal usaha, dengan kewajiban bagi pihak lainnya itu untuk pada waktunya membayar kembali dan memberi imbalan pada pihak pertama menurut bentuk, cara, jumlah, jangka waktu serta syarat yang telah disepakati. Perjanjian ini termasuk dalam ketentuan umum mengenai hukum perjanjian sebagaimana diatur dalam Buku III KUHPerdata, antara lain yang menyangkut syarat sahnya perjanjian serta asas-asas hukum perjanjian.

\section{Wanprestasi dan Akibat Hukumnya}

Setiap perjanjian yang dibuat oleh para pihak harus dilaksanakan secara sukarela, namun kadang kala perjanjian yang dibuat tersebut dilanggar oleh salah satu pihak karena dengan atau tanpa alasan tertentu. Pelanggaran itu bisa berupa pelaksanaan yang tidak sesuai dengan perjanjian atau tidak melaksanakannya Dalam suatu perjanjian, apabila debitur melanggar apa yang dijanjikannya, maka dapat dikatakan telah melakukan wanprestasi. Dapat dikatakan pula bahwa debitur lalai atau alpa atau ingkar janji bahkan melanggar perjanjian dengan melakukan sesuatu hal yang tidak boleh dilakukan.

Wanprestasi (kealpaan atau kelalaian) berupa prestasi atau kewajiban yang tidak dilaksanakan sebagaimana mestinya dalam perjanjian terhadap pihak- pihak tertentu seperti yang dimaksudkan dalam kontrak yang bersangkutan.(Fuady, 2006:87-88) Subekti kemudian menjelaskannya beberapa macama bentuk wanprestasi seorang debitur anatara lain: (Subekti, 1976: 45)

1. tidak melakukan apa yang disanggupi akan dilakukannya;

2. melaksanakan apa yang dijanjikannya, tetapi tidak sebagaimana dijanjikan;

3. melakukan apa yang dijanjikan, tetapi terlambat; dan

4. melakukan sesuatu yang menurut perjanjian tidak boleh dilakukannya. 
Dalam KUHPerdata, kelalaian dalam wanprestasi bisa berakibat sanksi atau hukuman berupa;

1. Membayar kerugian yang diderita oleh kreditur atau ganti rugi (Pasal 1234).

2. Pembatalan perjanjian melalui hakim (Pasal 1266).

3. Peralihan resiko kepada debitur sejak saat terjadinya wanprestasi (Pasal 1237 ayat (2)).

4. Membayar biaya perkara, apabila sampai diperkarakan di muka hakim (Pasal 181 ayat (1) HIR).

Karena dampak timbul dari wanprestasi yang memeberatkan bagi sala satu pihak, maka penetapan kondisi wanprestasi olehnya harus dilakukan terlebih dahulu. Penyangkalannya kemudian harus dibuktikan di muka hakim. Untuk itu perlu peringatan dini kepada pihak yang lalai. peringatan atau teguran secara lisan dan tegas dari kreditur sepaya prestasi dilakukan dengan seketika atau dalam waktu singkat. Suatu peringatan atau teguran lisan ini bertujuan agar nantinya dapat dipertanggungjawabkan di muka hakim, sebaiknya dibuat secara tertulis. surat perintah resmi tertulis kemudian diberikan oleh juru sita pengadilan apabila peringatan diabaikan dan terbukti. Semua itu diatur dalam Pasal 1238 KUH Perdata.

Apabila si berhutang adalah lalai, bila dengan surat perintah atau dengan sebuah akta sejenis itu telah dinyatakan lalai atau demi perikatannya sendiri menetapkan bahwa si berhutang akan harus dianggap lalai dengan lewatnya waktu yang ditentukan. Dalam Dari rumusan tersebut, dapat dijelaskan bahwa sebelum kepada debitur yang lalai, pada umumnya terlebih dahulu diberikan

Akibat adanya wanprestasi ini, maka perusahaan modal ventura (yang berhak menuntut prestasi) dapat menuntut kepada PPU (yang wajib memenuhi prestasi), yaitu berupa :(Ibid.)

1. Pemutusan perjanjian

2. Penggantiaan kerugian

3. Pemenuhan perjanjian disertai ganti kerugian

4. Pemutusan perjanjian disertai dengan ganti kerugian 
Sebelum tuntutan dilakukan, pihak PMV perlu melakukan upayaupaya awal untuk mengklasifikasikan apakah tindakan penuntutan itu harus diambil. Berdasarkan catatan dan data lampau, PMV dapat melakukan klasifikasi PPU yang berpotensi wanprestasi dengan melihat aspek-aspek penent unya, antara lain:

1. Aspek pemenuhan kewajiban.

PPU memenuhi kewajibannya dengan sebagaimana mestinya. Tidak terdapat tunggakan, baik pokok maupun bagi hasilnya.

2. Aspek kondisi keuangan.

Kondisi keuangan PPU berkembang dengan baik, usahanya berjalan dengan lancar sesuai yang disepakati bersama antara PMV dan PPU yang bersangkutan.

3. Aspek prospek usaha.

Reputasi, perkembangan perusahaan dan prospek PPU berada dalam keadaan baik, manajemen berjalan dengan baik, kapasitas pemasaran terus meningkat, pasokan bahan baku terjamin, sehingga dapat disimpulkan bahwa perusahaan tersebut dapat berjalan dengan kinerja yang optimal sampai beberapa waktu ke depan.

4. Aspek dokumentasi.

Seluruh perjanjian yang ada atas pembiayaan dengan pola bagi hasil kepada PPU, secara yuridis formal dijadikan alat bukti yang sempurna sesuai dengan hukum pebuktian yang berlaku.

5. Aspek asset

Asset yang ada sangat mencukupi dan dapat menjadi jaminan atas kewajiban-kewajiban Perusahaan Pasangan Usaha, apabila harus dilakukan penjualan asset untuk menutupi seluruh kewajibannya tersebut.

Dalam Buku II KHES pasal 207 memiliki aturan yang senada untuk mengatasi wanprestasi. Dalam pasal itu dijelaskan bahwa Pemilik modal dapat memberhentikan atau memecat pihak yang melanggar kesepakatan dalam akad mudharabah. Penghentian itu tidak bisa dilakukan seketika tetapi harus diberitahukan kepada mudharib yang wajib mengembalikan modal dan keuntungan kepada pemilik modal yang menjadi hak pemilik modal 
dalam kerjasama mudharabah. Perselisihan itu bisa didamaikan (sulh) melalui pengadilan

\section{Penutup}

1. Perjanjian pembiayaan dengan pola bagi hasil ditinjau dari bentuknya merupakan perjanjian baku yang telah terstandarisasi meski kemungkinan variasi dan perbedaan karakter usaha dari PPU sangat besar sehingga dan tidak bisa tercakup dalam bentuk baku. Hal yang sama terungkap dalam akad mudarabah meski demikian persyaratan pokok antara keduanya tidak terdapat jurang pemisah yang jauh.

2. Hak Dan Kewajiban PMV dan PPU ternyata belum mencerminkan iktikad baik masing-masing pihak sebagaimana yang seharusnya terjadi dalam perjanjian persekutuan perdata. PPU mendapatkan manfaat dari hak dan kewajibannya, namun manfaat PMV masih lebih besar sehingga perjanjian kemitraan masih perlu diperjelas lagi.

3. Penyelesaian wanprestasi dari pihak PPU dalam MV melalui KUHPerdata mempunyai potensi dikembangkan lebih jauh dalam mudarabah karena at uran dan penjelasan lebih detil. Pengaturan demikian bisa memposisikan PMV dan PPU dalam posisi yang seimbang dalam menyikapi wanprestasi secara hokum. Meski demikian KUHPerdata dan KHES tentang mudarabah sama-sama menjadikan pengadilan sebagai jalan terakhir bila penyelesaian di luar pengadilan mengalami jalan buntu.

\section{Daftar Pustaka}

Peraturan Otoritas Jasa Keuangan Nomor 35/Pojk.05/2015 tentang Penyelenggaraan Usaha Perusahaan Modal Ventura

Kitab Undang-undang Hukum Perdata

Kompilasi Hukum Ekonomi Syariah

Budisantoso, Totok dan Triandaru, Sigit. 2006. Bank dan Lembaga Keuangan Lain. Jakarta: Salemba Empat.

Hamid, Azwar. "Modal Ventura Syari'ah.” Al-Masharif Volume 3, No. 1, Januari-Juni 2015, hal. 139-154.

Kadarisman, KPHN Hoedhiono. 1995. Modal Ventura: Alternatif Pembiayaan 
Usaha Masa Depan, cet. 1. Jakarta: PT IBEC.

Mackulau, Andi Maradang. "Tinjauan Hukum Pembiayaan Bagi Hasil Modal Ventura" Rapat Executive Committee 4 November 2003.

Martono. 2004. Bank dan Lembaga Keuangan Lain. Yogyakarta: Ekonasia Kampus Fakultas Ekonomi UII.

Fuady, Munir. 2005. Pengantar Hukum Bisnis Menata Bisnis Modern di Era Global. Bandung: PT. Citra Aditya Bakti.

Fuady, Munir. 2006. Hukum tentang Pembiayaan. Bandung: PT. Citra Aditya Bakti.

Pandia, Frianto Elly Santi Ompusunggu dan Achmad Abror. 2005. Lembaga Keuangan. PT. Rineka Cipta: Jakarta.

Patrik, Purwahid. 1994. Dasar-dasar Hukum Perikatan, Perikatan yang lahir dari Perjanjian dan dari Undang-undang. Bandung: Mandar Maju.

PT. Bahana Artha Ventura. 1996. Ketentuan Pokok Pembiayaan Perusahaan Modal Ventura. Jakarta: tnp.

Rahman, Hasanuddin. 2003. Segi-segi Hukum \& Manajemen Modal Ventura. Bandung: PT. Citra Aditya Bakti.

Santoso, F. Setiawan. "Pola Pembiayaan Modal Ventura Di Indonesia, Ekplorasi Bagi Upaya Pengembangannya Di Ekonomi Syariah," Jurnal ilmu-ilmu Keislaman Ulumuddin, volume 5 nomor 2, hal. $39-49$

Simorangkir, O. P. 2004. Pengantar Lembaga Keuangan Bank dan Non Bank. Jakarta: Ghalia Indonesia.

Subekti, R. 1976. Aspek-aspek Hukum Perikatan Nasional. Bandung: Alumni. Sunaryo, 2008. Hukum Lembaga Keuangan, Jakarta: tnp. 